\title{
Mobile E-Commerce Website for Technology-Based Buying Selling Services
}

\author{
Eti Sri Asih, Kasmi, Phong Thanh Nguyen, E. Laxmi Lydia, K. Shankar, Wahidah Hashim, \\ Andino Maseleno
}

\begin{abstract}
Buying and selling mobile phones which located at Raya Kedondong Street Waylima Subdistrict, Pesawaran District is a store that is engaged to develop, improving, and promoting the store so that it can be known outside the region. So with this, it is necessary to give easy service to the customers who are far from reach. It can be realized by (E-Commerce). Then an application system was built to help the service information about buying and selling mobile phones which uses the SDLC method, that will produce an information system related to buying and selling mobile phones. With this application, it will help the seller in managing data of ordering goods, customer data, and facilitate consumers in finding information about prices and brands of mobile phones.
\end{abstract}

Keywords: Web mobile, Buying and Selling, E-Commerce.

\section{INTRODUCTION}

\section{A. Research Background}

The development of Information Technology today is very rapid and continuous, and the industrial world of business today has increased [1-3]. Competition between industries to dominate the market is very large. This condition certainly must be examined in order to get around the competition. This makes industries increasingly appear in various types of industrial fields in various places [4-6]. One use of information technology that makes communication easier is the Internet [7-9]. With the internet, business people have no longer difficulty in obtaining any information, to support their business activities, even now it tends to be able to obtain various kinds of information, so that information must be filtered to obtain appropriate and relevant information [10-12].

The great benefits of information technology, making E-Commerce give a big impact on the development of business practices, namely in terms of sales to perfect direct

Revised Manuscript Received on July 22, 2019.

Eti Sri Asih, Department of Information Systems, STMIK Pringsewu, Lampung, Indonesia.

Kasmi, Department of Information Systems, STMIK Pringsewu, Lampung, Indonesia.

Phong Thanh Nguyen, Department of Project Management, Ho Chi Minh City Open University, Vietnam.

E. Laxmi Lydia, Vignan's Institute of Information Technology (A), Department of Computer Science and Engineering, Visakhapatnam, Andhra Pradesh, India.

K. Shankar, Department of Computer Applications Alagappa University, India.

Wahidah Hashim, Institute of Informatics and Computing Energy, Universiti Tenaga Nasional, Malaysia.

Andino Maseleno, Institute of Informatics and Computing Energy, Universiti Tenaga Nasional, Malaysia. marketing, such as organizational transformation and organizational redefinition [13-15]. This business model suppresses information exchange and transactions, businesses use other technologies that are also network-based. Basically, E-Commerce is doing online business. In its clearest form, E-Commerce sells the products to consumers online, but the fact is that any type of business that is conducted electronically is called E-Commerce. Simply, E-Commerce is creating, managing, and expanding commercial relationships online.

With the weakness of the cell phone buying and selling service, it is necessary to design and develop a website-based system to facilitate customers in making transactions and ordering goods and can help meet the consumers needs. Based on the previous explanation, the researcher is interested in conducting research and making a new web-based information system to develop, improve, and promoting so that it can be known outside the region under the title "Mobile e-commerce website for technology-based buying selling services"

\section{B. Research Question}

To make the problems discussed are not too extensive and can be more focused on analyzing and designing the system, then limiting the problem, including: How to build an E-Commerce in mobile buying and selling service?

\section{Research Limitation}

The limitations of the problem in this research are as follows :

1. Only used for the traders of buying and selling mobile phones.

2. This application uses a database system so all the defective data is safe.

3. The price of each handphone is entered manually and can be edited by the traders according to the price.

\section{Research Objectives}

From the description of the main problems above, the purpose of this research is to design and build an e-commerce-based mobile sales information system.

\section{E. Benefits of Research}

The benefits of this research are as follows:

1. The availability of more attractive information, that is integrated directly with ordering and payment confirmation.

2. Reducing the time of ordering goods 


\section{THEORETICAL FRAMEWORK}

\section{A. Definition of E-Commerce}

Electronic Commerce (E-Commerce) is the process of buying, selling or exchanging products, services, and information through a computer network. E-Commerce is a part of e-business, where the scope of e-business is broader, not just commerce but also includes collaborating business partners, customer service, job vacancies, etc. In addition to www network technology, E-Commerce also requires database or database technology, e-mail, and other forms of non-computer technology such as goods delivery systems, and payment instruments for E-Commerce. E-Commerce or electronic commerce is all forms of buying and selling activities, marketing of service products and information conducted electronically. The buying, selling, and marketing of goods and services through an electronic system. Like Television, Radio and Computer Networks or the Internet ".

\section{B. Service}

Service is an attitude or way of serving customers so that customers get the satisfaction which includes speed, accuracy, friendliness, and comfort.

Customer Service is another element of the product strategy, the company's offer to the market usually includes several services, which can form a large or small part of the overall offer. Companies should design their supporting products and services to meet the desires of customers who become their target market profitably.

\section{Buying and Selling}

Buying and selling according to language mean exchange. Meanwhile, according to the definition of fiqh, buying and selling are exchanging an item for other goods in harmony and certain conditions. Buying and selling can also be interpreted as exchanging money for the desired goods according to specific terms and conditions. After buying and selling is done legally, the goods sold to become the property of the buyer while the money paid by the buyer as a substitute for the price of the goods becomes the property of the seller. Which is located at Raya Kedondong Street Waylima Subdistrict, Pesawaran District.

One day the Prophet Muhammad SAW was asked by a friend about the best job. He answered the best job is a work done with his own hands and buying and selling done well. Buying and selling should be done by traders who understand the science of fiqh. This is to avoid fraud from both parties. Caliph Umar bin Khattab, very concerned about buying and selling that occurred in the market. He expelled traders who did not know the science of fiqh for fear of buying and selling carried out not following Islamic law.

At present, the way of buying and selling is develop. In supermarkets or malls, buyers can choose and pick up the items needed without dealing with the seller. The seller's statement (consent) is manifested in the price list of goods or the price tag of the goods sold while the statement of the buyer (Kabul) is the act of the buyer paying for the items he takes.

\section{D.Technology}

Technology is a knowledge that is aimed to create tools, processing and extracting objects [16-18]. The term of "technology" is widely known and everyone has their way of understanding technology. Technology is used to solve various problems in our daily lives, shortly; we can describe technology as a product, process, or organization [19-21]. Besides, technology is used to expand our capabilities, and it makes people think that technology are the most important part.

Technology is also the application of science to solve problems. But what we have to know is that technology and science are different subjects that work hand-in-hand to complete a particular task or solve a particular problem [22-24].

Technology is a form of process that increases added value. The running process can use or produce certain products, where the product produced is not separate from other existing products. Furthermore, it is also mentioned that technology is a part of an integral found in a particular system.

Technology is an object as well as an object, as well as material and also a different form compared to ordinary humans.

\section{E. Mobile}

Mobile can be interpreted as an easy move from one place to another, for example, a mobile telephone means that a telephone terminal that can move easily from one place to another without disconnection or communication is interrupted.

The mobile application system is an application that can be used even if the user moves easily from one place to another without interruption of communication. This application can be accessed through wireless devices such as pagers, such as cellular phones and PDAs.

Mobile applications come from words of application and mobile. Application which means application, proposal, usage. In term, application is a ready-made program designed to carry out a function for other users or applications and can be used by targets intended while for mobile can be interpreted as moving from one place to another.

Mobile Commerce is all about wireless e-commerce where mobile devices are used to do business on the Internet.

\section{F. Website}

A website is a gathering place for web pages that are usually summarized in a domain or subdomain on the World Wide Web on the Internet.

Website is a system that deals with documents that are used as media to display text, images, multimedia, and others on the internet network.

Website or site can be interpreted as a collection of pages that are used to display text, still or motion pictures, animations, sounds or a combination of both static and dynamic.

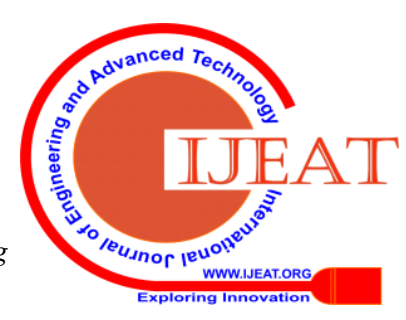




\section{METHODOLOGY}

\section{A. Data Collecting Method}

In preparing this paper, it is necessary to have a certain method that will be used in collecting data obtained by the following methods:

\section{Interview Method}

Interview is a conversation between the researcher and the informant. The researcher is someone who get information, while the informant is someone who give information or assume to have important information about an object. Interviews are conducted directly with village officials, the community, and related agencies regarding the village government system and the potentials in the village.

\section{Observation Method}

The method of observation is a research method in which, the researcher conduct observations or see and examine directly to the object of research about all activities related to research purposes, by analyzing evaluating the current system and providing solutions through the information system to be built so that it can be more useful.

\section{B. Development System Method}

The data obtained were then analyzed to develop the existing system to obtain better results. System Development Life Cycle (SDLC) in system engineering and software engineering is the process of making and changing the system and the models and methodologies used to develop systems. The SDLC is also the stages of work carried out by system analysts and programmers in building information systems.

The stages can be seen as the picture above.

\section{Planning}

At this stage, the focus is more on interpreting the needs and diagnosing problems by defining the goals and objectives of the system to be built.

\section{System Analysis}

In this stage, the researcher analysed the existing system with the method used namely interviews with relevant parties and observed the condition of the village which is the scope of the study. In this stage include: determining the object, studying the organization, analyzing output requirements, analyzing input requirements, evaluating system effectiveness.

\section{System design}

In designing this system it was based on the needs and problems encountered in the research object. In this stage includes database design, user interface design, hardware requirements, network design, software requirements.

\section{System Implementation}

System implementation is the construction, installation, testing, and delivery of the system into production (daily operations). The implementation of the system constructs a new information system and puts it into operation, then the testing was carried out.

\section{Maintenance}

Maintenance is intended so that the system that has been implemented can follow any developments and changes that occur to achieve the intended use.

\section{IMPLEMENTATION}

\section{A. Login Page}

The login page is shown in figure 1.

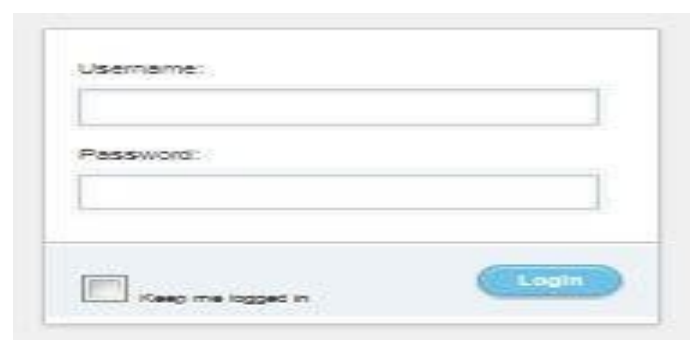

Figure 1. Login page

\section{B. Administrator Page}

The administrator page is shown in figure 2 .

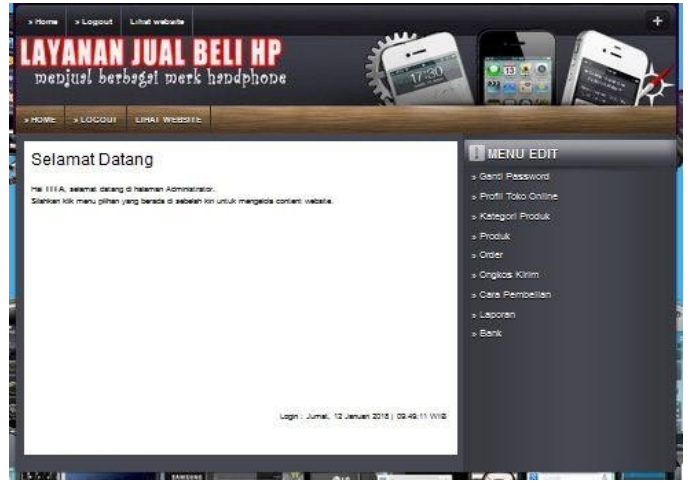

Figure 2. Admin Page Display

\section{Homepage Display}

To open this page by clicking on the homepage menu so that information will appear on the homepage menu while displaying from the homepage menu is shown in figure 3 .

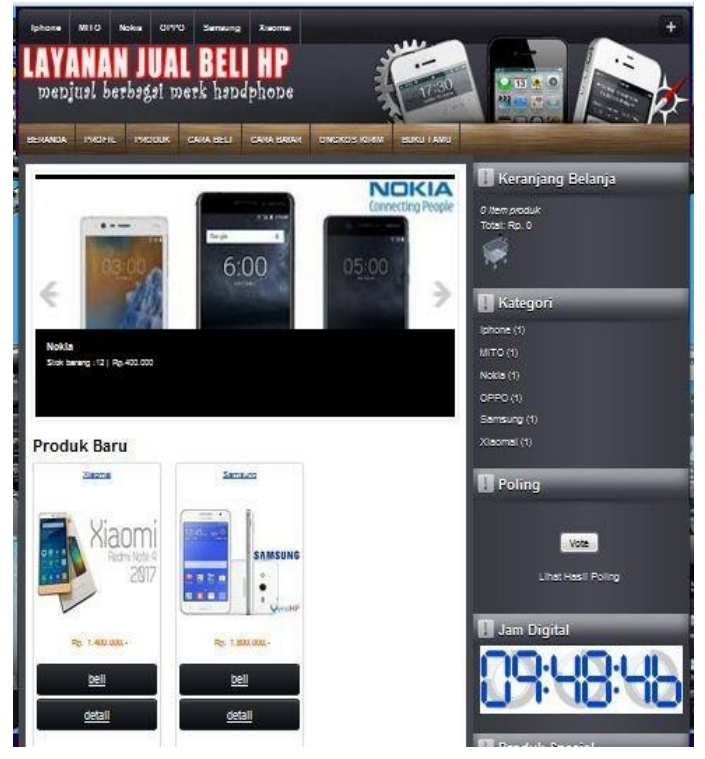

Figure 3. Homepage

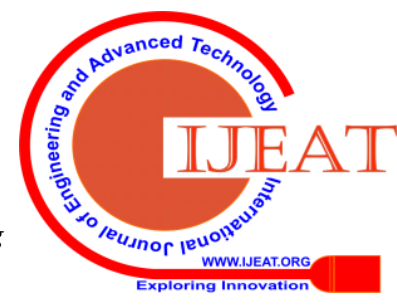




\section{Profile Page Display}

Figure 4 shows profil page.

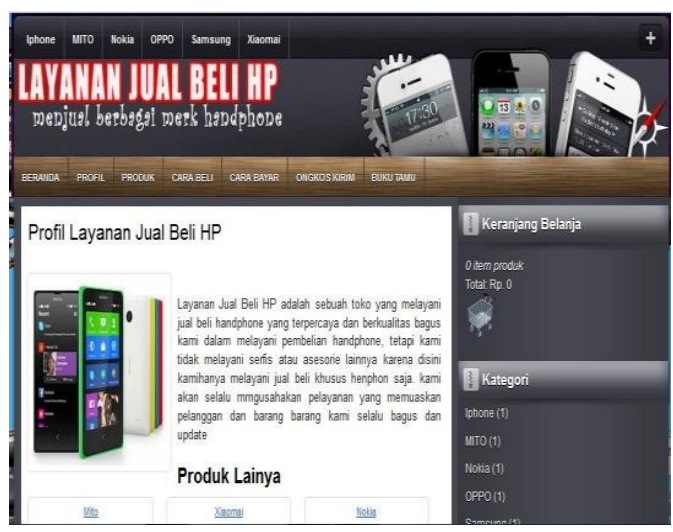

Figure 4. Profile page display

\section{CONCLUSION AND SUGGESTION}

\section{A. Conclusion}

Based on research conducted by the researcher, and the results of the discussion described in previous chapters, the researcher conclude that:

With the application of the Mobile Commerce Application can help the seller in managing data ordering goods, customer data, and confirmation of delivery of goods.

\section{B. Suggestion}

From the results described above. The researcher suggest for the next development process :

1. For further development, it is expected to add supporting function facilities such as push notifications on mobile applications that help customers to see new products.

2. The design of this application is also implemented by using an iPhone-based application so that all smartphone users can use this application.

\section{REFERENCES}

1. Ambika, P., Ayshwarya, B, Livshits, Y.A., Nguyen, P.T., Hashim, W., Shankar, K., Maseleno, A., Self-education as a condition of professional and personal development of a future specialist, Religación. Revista de Ciencias Sociales y Humanidades, Vol. 4, No. 16, 2019. pp. 499-205. (ESCI WOS) http://revista.religacion.com/index.php/about/article/view/292/251

2. Kumar, R., Ayshwarya, B., Konovalova, E.Y., Nguyen, P.T., Hashim, W., Shankar, K., Maseleno, A., Approaches and technologies for the formation of future specialists' motivation, Religación. Revista de Ciencias Sociales y Humanidades, Vol. 4, No. 16, 2019. pp. 492-498. (ESCI

http://revista.religacion.com/index.php/about/article/view/291/250

3. Rusliyadi, M., Kumalasari, R.T., Nguyen, P.T., Hashim, W., Maseleno, A., Potential Jatropha Curcas (Jatropha Curcas L.) Germplasm by Exploration In Gorontalo Province Indonesia, International Journal of Recent Technology and Engineering (IJRTE), Vol. 8, Issue 2S3, 2019. pp.1617-1624.

(Scopus) https:/www.ijrte.org/wp-content/uploads/papers/v8i2S3/B12950782S31 9.pdf

4. Ambika P., Ayshwarya, B., Nguyen, P.T., Hashim, W., Rinjani, F., Muslihudin, M., Shankar, K., Denisova, O.P., Maseleno, A., The Best of Village Head Performance: Simple Additive Weighting Method, International Journal of Recent Technology and Engineering (IJRTE), Vol. 8, Issue 2S3, 2019. pp.1568-1572. (Scopus)
https://www.ijrte.org/wp-content/uploads/papers/v8i2S3/B12860782S31 $\underline{\text { 9.pdf }}$

5. Sivaram, M., Ayshwarya, B., Hashim, W., Nguyen, P.T., Shankar, K., Prabowo, E., Abadi, S., Huda, M., Ochepovsky, A.V., Maseleno, A. School Now, Pay Later, Revista San Gregorio, No. 32, Special Issue August 2019. pp. 196-203. (ESCI WOS) http://revista.sangregorio.edu.ec/index.php/REVISTASANGREGORIO/ article/view/1075/TRR6

6. Sivaram, M., Ayshwarya, B., Pribadi, M.R., Nguyen, P.T., Shankar, K., Mohammed, A.S., Abadi, S., Huda, M., Putra, D.P., Hashim, W. Maseleno, A., Porkodi, V., Manikandan, V., Ochepovsky, A.V., Saving Private Money, Revista San Gregorio, No. 32, Special Issue August 2019. pp. 204-211. (ESCI http://revista.sangregorio.edu.ec/index.php/REVISTASANGREGORIO/ article/view/1077/trr7

7. Maseleno, A., Ayshwary, B., Ivanova, T.N., Hashim, W., Nguyen, P.T., Shankar, K., Kristiawan, M., Huda, M., General theoretical and philosophical aspects of modern education, Revista San Gregorio, No. 32, Special Issue August 2019. pp. 212-217. (ESCI WOS) http://revista.sangregorio.edu.ec/index.php/REVISTASANGREGORIO/ article/view/1079/trr8

8. Ayshwarya, B., Nguyen, P.T., Bazar, F.A., Aminudin, N., Shankar, K., Hashim, W., Larisa N. Gorina, Maseleno, A., Aqua Bill Store Mineral Water Sales Application Program, International Journal of Recent Technology and Engineering (IJRTE), Vol. 8, Issue 2S3, 2019. pp.1495-1499.

(Scopus) https://www.ijrte.org/wp-content/uploads/papers/v8i2S3/B12740782S31 9.pdf

9. Mukhlis, H., Ayshwarya, B., Nguyen, P.T., Hashim, W., Hardono, Maesaroh, S., Sagita, Y.D., Surmiasih, Sanjaya, R., Oktafianto, Shankar, K., Denisova, O.P., Maseleno, A., Boarding House Selection using SAW Method, International Journal of Recent Technology and Engineering (IJRTE), Vol. 8, Issue 2S3, 2019. pp.1500-1506. (Scopus) https://www.ijrte.org/wp-content/uploads/papers/v8i2S3/B12750782S31 9.pdf

10. Ayshwarya, B., Yansyah, A., Nguyen, P.T., Shankar, K., Hashim, W., Satria Abadi, S., Odarich, I.N., Maseleno, A., Design Analysis of Web-Based Employee Information System in Office of Technical Implementation Unit of Education Department, International Journal of Recent Technology and Engineering (IJRTE), Vol. 8, Issue 2S3, 2019. pp. $1507-1512$.

(Scopus) https://www.ijrte.org/wp-content/uploads/papers/v8i2S3/B12760782S31 9.pdf

11. Ayshwarya, B., Nguyen, P.T., Alismi, Satria Abadi, Shankar, K., Hashim W., Aleksandr A. Korostelev, Maseleno, A., Design Analysis of Web-Based Furniture Marketing Information System, Internationa Journal of Recent Technology and Engineering (IJRTE), Vol. 8, Issue 2S3, 2019. pp.1513-1519. (Scopus) https://www.ijrte.org/wp-content/uploads/papers/v8i2S3/B12770782S31 9.pdf

12. Ayshwarya, B., Firdiansah, F.A., Firmansyah Y. Alfian, F.Y., Nguyen, P.T., Hashim, W., Shankar, K.,Abadi, S., Peteraitis, S.K., Maseleno, A., The Best Land Selection using SAW, International Journal of Recent Technology and Engineering (IJRTE), Vol. 8, Issue 2S3, 2019. pp.1520-1525.

(Scopus) https://www.ijrte.org/wp-content/uploads/papers/v8i2S3/B12780782S31 9.pdf

13. Ayshwarya, B., Nguyen, P.T., Alfian, F.Y., Hashim, W., Shankar, K., Aprilda, Y., Ipnuwati, S., Melnikov, P.A., Maseleno, A., The Good Salted egg using AHP, International Journal of Recent Technology and Engineering (IJRTE), Vol. 8, Issue 2S3, 2019. pp.1526-1532. (Scopus) https://www.ijrte.org/wp-content/uploads/papers/v8i2S3/B12790782S31 9.pdf

14. Kumar R., B. Ayshwarya, Muhamad Muslihudin, Nguyen, P.T., Firmansyah Y. Alfian, Hashim, W., Shankar, K., Siti Hafizah, Siti Mukodimah, Irina N. Odarich, Maseleno, A., Into the Furniture Woods: Analytical Hierarchy Process Method, International Journal of Recent Technology and Engineering (IJRTE), Vol. 8, Issue 2S3, 2019. pp.1562-1567.

(Scopus) https://www.ijrte.org/wp-content/uploads/papers/v8i2S3/B12850782S31 9.pdf

15. Muslihudin, M., Trisnawati, Mukodimah, S., Hashim, W., Ayshwarya, B., Nguyen, P.T., Shankar, K., Peteraitis, S.K., Maseleno, A. Performance of SAW and WP Method in Determining the Feasibility of Motorcycle Engineering Workshop for Competency Test of Vocational High School

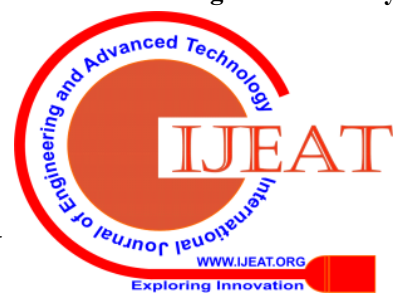


Student, International Journal of Recent Technology and Engineering (IJRTE), Vol. 8, Issue 2S2, July 2019. pp. 348-353. (Scopus) https://www.ijrte.org/wp-content/uploads/papers/v8i2S2/B10600782S21 9.pdf

16. Deviana, H., Amin, M.M., Sandy, R., Nguyen, P.T., Hashim, W., Maseleno, A., Door Security Design using Radio Frequency Identification With a Short Message Service Warning System, International Journal of Recent Technology and Engineering (IJRTE), Vol. 8, Issue 2S2, July 2019. pp. 354-370. (Scopus) https://www.ijrte.org/wp-content/uploads/papers/v8i2S2/B10610782S21 9.pdf

17. Amin, M.M., Hartati Deviana, H., Andika, R., Nguyen, P.T., Hashim, W., Maseleno, A., Computer Numerically Controlled Machine to Draw text on Ardunio-based Acrylic Board, International Journal of Recent Technology and Engineering (IJRTE), Vol. 8, Issue 2S2, July 2019. pp. 371-384. (Scopus) https://www.ijrte.org/wp-content/uploads/papers/v8i2S2/B10620782S21 9.pdf

18. Muslihudin, M., Ayshwarya, B., Effendi, Yusfika, D., Pribadi, M.R., Susanto, F., Hashim, W., Nguyen, P.T., Maseleno, A., Mukodimah, S., Vellyana, D., Application of Weighted Product Method for Determining Home Renovation Assistance in Pringsewu District, International Journal of Recent Technology and Engineering (IJRTE), Vol. 8, Issue 2S2, July 2019. pp. 385-391. (Scopus) https://www.ijite.org/wp-content/uploads/papers/v8i2S2/B10630782S21 9.pdf

19. Ayshwarya, B., Soim, A., Nguyen, P.T., Shankar, K., Hashim, W., Abadi, S., Andino Maseleno, Web Based-Decision Support System to Diagnose Hepatitis Disease using SAW Method, International Journal of Innovative Technology and Exploring Engineering (IJITEE), Vol. 8, Issue 9S3, July 2019. pp. 117-123. (Scopus) https://www.ijitee.org/wp-content/uploads/papers/v8i9S3/I30240789S31 9.pdf

20. Smirnova, E.V., Ayshwarya, B., Nguyen, P.T., Hashim, W., Maseleno, A., Using Shell Programs in Educational and Methodological Support for Learning Foreign Language, International Journal of Applied Exercise Physiology, Vol. 8 (2.1), 2019. pp. 1027-1032. (ESCI WOS) http://ijaep.com/Journal/vol.8.2.1.pdf

21. Rakhimbaeva, I.E., Korostelev, A.A., Shakirova, I.A., Ayshwarya, B., Nguyen, P.T., Hashim, W., Maseleno, A., Integration of the Educational and Didactic Systems in the Training of Future Teachers, International Journal of Applied Exercise Physiology, Vol. 8 (2.1), 2019. pp. 1033-1038. (ESCI WOS) http://ijaep.com/Journal/vol.8.2.1.pdf

22. Busygina, A.L., Chertakova, E.M., Darya B. Shtrikova, D.B., Ayshwarya, B., Nguyen, P.T., Hashim, W., Maseleno, A., Professional forms of Employment in the Russian Federation: Problems and Challenges, International Journal of Applied Exercise Physiology, Vol. 8 (2.1), 2019. pp. 1039-1045. (ESCI WOS) http://ijaep.com/Journal/vol.8.2.1.pdf

23. Pugach, O.I., Ochepovsky, A.V., Hashim, W., Maseleno, A., Ayshwarya, B., Nguyen, P.T., To the use of English Words When Learning Programming, Information Systems and Technologies, International Journal of Applied Exercise Physiology, Vol. 8 (2.1), 2019. pp. 1046-1051. (ESCI WOS) http://ijaep.com/Journal/vol.8.2.1.pdf 